University of Nebraska - Lincoln

DigitalCommons@University of Nebraska - Lincoln

2000

\title{
Consequences of Antenna Design in Telemetry Studies of Small Passerines
}

Steve J. Dougill

U.S. Geological Survey

Luanne Johnson

U.S. Geological Survey

Paul C. Banko

U.S. Geological Survey

Dan M. Goltz

U.S. Geological Survey

Michael R. Wiley

U.S. Geological Survey

See next page for additional authors

Follow this and additional works at: https://digitalcommons.unl.edu/usgsstaffpub

Dougill, Steve J.; Johnson, Luanne; Banko, Paul C.; Goltz, Dan M.; Wiley, Michael R.; and Semones, John D., "Consequences of Antenna Design in Telemetry Studies of Small Passerines" (2000). USGS Staff -Published Research. 642.

https://digitalcommons.unl.edu/usgsstaffpub/642

This Article is brought to you for free and open access by the US Geological Survey at DigitalCommons@University of Nebraska - Lincoln. It has been accepted for inclusion in USGS Staff -- Published Research by an authorized administrator of DigitalCommons@University of Nebraska - Lincoln. 


\section{Authors}

Steve J. Dougill, Luanne Johnson, Paul C. Banko, Dan M. Goltz, Michael R. Wiley, and John D. Semones 


\title{
JOURNAL OF FIELD ORNITHOLOGY
}

Published by

\author{
Association of Field Ornithologists
}

\begin{tabular}{lll}
\hline Vol. 71, No. 3 & Summer 2000 & PAGES 385-572 \\
\hline
\end{tabular}

J. Field Ornithol., 71(3):385-388

\section{CONSEQ UENCES OF ANTENNA DESIGN IN TELEMETRY ST UDIES OF SMALL PASSERINES.}

\author{
Steve J. Dougill, Luanne Johnson, Paul C. Banko, Dan M. Goltz, \\ Michael R. Wiley, and John D. Semones \\ U.S. Geological Survey \\ Biological Resources Division \\ Pacific Island Ecosystems Research Center \\ P.O. B ox 44 \\ Kilauea Field Station \\ H awaii Volcanoes National Park, H awaii 96718 USA
}

Abstract.-Entanglement and mortality of Palila ( L oxioides bailleui), an endangered $\mathrm{H}$ awaiian honeycreeper, occurred when birds were radio-tagged with transmitters equipped with a long, limp, solder-tipped antenna. Birds were found suspended in trees by their transmitter antenna on eight occasions. Although these birds eventually freed themselves or were freed by us, at least one bird died afterwards. For radio telemetry studies of small passerine species we recommend avoiding transmitters equipped with an antenna that is bulbous at the tip, >16 $\mathrm{cm}$ in length, limp, and shiny.

\section{CONSECUENCIAS EN EL DISEÑO DE UNA ANTENA EN UN ESTUDIO DE RADIOTELEMETRIA PARA PASERINOS}

Sinopsis.-En estudio de radiotelemetría que se llevó a cabo en Loxiodes bailleui se encontraron aves enredadas y una que murió. En ocho ocasiones se encontraron aves suspendidas en la vegetación atadas a esta por la larga antena con punta en forma de bulbo. Aunque algunas aves lograron liberarse y otras fueron liberadas por el grupo de trabajo, al menos una murió. Para el estudio de pequeños paserinos, utilizando radiotelemetría, no recomendamos el utilizar antenas brillantes de $>16 \mathrm{~cm}$ de largo, con punta en forma de bulbo.

Advances in transmitter technology make radio telemetry a feasible technique for the study of many small passerine species. Factors influencing the choice of a transmitter for a small bird include cost, weight, battery longevity, signal pulse rate, frequency, sealing material, and maximum detection distance. Furthermore, there are choices about where and how to attach the transmitter to the bird. From our experiences with an endangered $\mathrm{H}$ awaiian honeycreeper, the Palila (Loxioides bailleui), we suggest that the style and design of the antenna also is a vital consideration.

The Palila is a stocky, finch-billed honeycreeper weighing $32-45 \mathrm{~g}$ and 
found only in the subalpine forest of Mauna Kea volcano on the island of Hawai'i ( Jacobi et al. 1996; Pratt et al. 1997). Palila inhabit woodland that is dominated by two tree species, mamane (Sophora chrysophylla) and naio (M yoporum sandwicense) (Scott et al. 1986; Hess et al. 1999).

Radio telemetry has been employed in a number of studies of the Palila to estimate home range size and determine movement patterns, to assess foraging behavior, to monitor re-nesting attempts after clutch removal for captive propagation, and to monitor survival and dispersal patterns of translocated birds (Fancy et al. 1993; Fancy et al. 1996; U SGS-BRD, unpubl. data). Two models of transmitter and two methods of attachment have been used in Palila studies. The most common model (model A) weighed less than $2 \mathrm{~g}$, functioned for $\leq 8 \mathrm{wk}$, and was attached interscapularly with glue (modified from Raim 1978; described by Fancy et al. 1993). The 16-cm antenna was made of $2.09 \mathrm{~kg}$-test braided stainless steel with a black nylon coating. This wire is commercially available as fishing leader material from The American Fishing Wire Company (West Chester, Pennsylvania). The antenna was stiff enough to extend on a nearly horizontal plane without support. Between 1990 and the spring of 1997, model A transmitters were attached to 114 Palila with no resulting complications (Fancy et al. 1993; U SGS-BRD, unpubl. data). In addition, egg fertility and hatchability was unaffected (USGS-BRD, unpubl. data).

We attached another model transmitter (model B) with figure-8 style elastic harnesses (Rappole and Tipton 1991) to 16 hatching-year Palila that were translocated in the autumn of 1997. We decided against the glue-on method because body molt during autumn would have caused the radio to fall off prematurely ( Jeffrey et al. 1993). The model B transmitter, which had a similar weight and battery life as the model A transmitter, was chosen because it was less expensive and had been used effectively for translocation of O mao (M yadestes obscurus; J. Nelson, pers. comm.) and studies of Nightingale Reed-Warblers (A crocephalus lu scinia; S. Mosher, pers. comm.). The antenna was $20-\mathrm{cm}$ long ( $4 \mathrm{~cm}$ longer than model A transmitters) and consisted of limp braided wire (SAVA 2014 stainless steel wire) that hung down nearly vertically from the transmitter body. To prevent the braided wire from unraveling, a small lump of solder had been added by the manufacturer to the end of the antenna.

Four Palila with model B transmitters were found suspended by their antennas on seven occasions between 26 N ov. 1997 and 5 Mar. 1998. Birds became entangled in live naio and mamane trees and a mamane snag in at least four different ways: (1) antenna wrapped around terminal leaves, (2) antenna wrapped around larger branches, (3) antenna wrapped around the fork of small branches, and (4) antenna caught under loose bark. Jackson et al. (1977) cautioned that researchers should be aware of the latter type of entanglement when working with birds that forage on tree surfaces. Each of the four Palila freed themselves from entanglement on at least one occasion; however we inter vened on three other occasions to release entangled birds. When problems with the model $B$ antenna design became apparent we attempted to remove the transmitters from 
all birds by strategically placing mist nests. $\mathrm{H}$ owever, the only individuals we were able to recapture where those that became snagged by their antennas in trees. O n 5 Jan. 1998, a Palila was freed from a mamane tree, but escaped before the transmitter could be removed and precautionary first aid administered. The bird was found dead $36 \mathrm{~h}$ later. There was no evidence of predation or scavenging, and the necropsy results suggest that the bird probably died of stress from being caught in the tree (T. Work, pers. comm.).

A fifth Palila was observed hanging limply from its radio transmitter antenna 5-m high in a dense mamane tree on $5 \mathrm{Mar}$. 1998. The bird became active and began fluttering when approached. With its antenna still caught, the bird looped itself three times around a branch, the radius of this gymnastic maneuver being the length of the taut transmitter antenna. After the third loop, it freed itself and flew to a neighboring tree. Later in the same day, the bird was observed foraging normally in mamane trees. After nearly 5 mo on the bird, the antenna had developed a large hook at the tip, which became frequently but temporarily snagged on branches and leaves as it dragged behind. The bird's movements were substantially impaired.

The harness method of transmitter attachment (used with model B) has been used successfully by many field workers and was not considered to be a problem in this study. However, we obser ved problems with transmitters fitted with long braided wire (model B) antennas. It seems likely that birds fitted with model B transmitters became entangled on more occasions than we observed but were able to free themselves. Birds flapping and struggling while entangled could attract predators or become weakened or injured and more vulnerable to predation or star vation even if they did manage to free themselves. In addition, the shiny appearance of model $B$ antennas may have made the birds more conspicuous to diurnal predators. The model $B$ antenna design may have contributed to the mortality of at least 7 of 15 Palila that died before battery failure. We removed transmitters from two translocated Palila, but three others were not seen after their transmitter batteries died. Two Palila with model B radios were alive $6 \mathrm{mo}$ after being translocated. After discovering the hazards of model B transmitters, we translocated 22 Palila with model A transmitters during 27 Jan-23 Apr. 1998.

We observed 16 birds equipped with model B transmitters on 305 occasions, and on eight occasions birds were caught in trees by their antenna. By contrast, the 22 birds equipped with model A transmitters were experiencing no problems on the 307 occasions that we observed them.

We suggest four design features to avoid when choosing a radio transmitter for a small passerine species: (1) a soldered, unfiled tip on the antenna, (2) an excessive antenna length (but consult the manufacturer for trade-offs with detection distance), (3) a shiny antenna wire that may attract predators, and (4) a limp antenna that may become entangled in vegetation or caught in rough or loose bark. 


\section{ACKNOWLEDGMENTS}

The following people assisted us with Palila translocation and radio-tracking: Kerri Boomgarden, Christopher Burney, Clem Dabrowski, Christopher Hoefer, Kyra Kopestonsky, Michael Layes, Andrew Mclntyre, Katy Mirowsky, Colleen Murray, Kirstin Rothrock, Joseph Smith, and Sabrina Taylor. The U.S. Army Garrison, H awaii provided funding. The Hawaii Division of Forestry and Wildlife and the U.S. Fish and Wildlife Service permitted us to radio-tag and translocate Palila. Jason Moniz allowed us access to the translocation site.

\section{LITERATURE CITED}

Fancy, S. G., R. T. Sugihara, J. T. Jefrerey, And J. D. Jacobi. 1993. Site tenacity in the endangered Palila. Wilson Bull. 105:587-596.

, T. J. SNETSINGER, AND J. D. JACOBI. 1996. Translocation of the Palila, an endangered H awaiian honeycreeper. Pac. Cons. Biol. 3:39-46.

Hess, S. C., P. C. BANKo, G. J. BRENNER, AND J. D. JACOBI. 1999. Factors related to the recovery of subal pine woodland on Mauna Kea, Hawaii. Biotropica 31:212-219.

JACKSON, J. A., B. J. SChARDien, AND G. W. Robinson. 1977. A problem associated with the use of radio transmitters on tree surface foraging birds. Inland Bird Banding News 49: 50-53.

Jacobi, J. D., S. G. Fancy, J. G. Giffin, AND J. M. Scott. 1996. Long-term population variability in the Palila, an endangered Hawaiian honeycreeper. Pac. Sci. 50:363-370.

Jefrrey, J. J., S. G. Fancy, G. D. Lindsey, P. C. Banko, T. K. Pratt, and J. D. Jacobi. 1993. Sex and age identification of Palila. J. Field Ornithol. 64:490-499.

Pratt, T. K., P. C. Banko, S. G. Fancy, G. D. Lindsey, and J. D. Jacobi. 1997. Status and management of the Palila, an endangered Hawaiian honeycreeper, 1987-1996. Pac. Cons. Biol. 3:330-340.

RaIm A. 1978. A radio transmitter attachment for small passerines. Bird Banding 49:26-332.

RAPPOLE, J. H., AND A. R. TIPTON. 1991. New harness design for attachment of radio transmitters to small passerines. J. Field Ornithol. 62:335-337.

Scott, J. M., S. Mountainspring, F. L. Ramsey, and C. B. Kepler. 1986. Forest bird communities of the Hawaiian Islands: their dynamics, ecology and conservation. Stud. Avian Biol. 9:1-431.

Received 19 O ct. 1998; accepted 14 May 1999. 